\title{
ЕФЕКТИВНІСТЬ ГІБРИДНИХ АРТЕРІАЛЬНИХ РЕКОНСТРУКЦІЙ У ХВОРИХ НА ЦУКРОВИЙ ДІАБЕТ ІЗ КРИТИЧНОЮ ІШЕМІЕЮ НИЖНЬОЇ КІНЦІВКИ
}

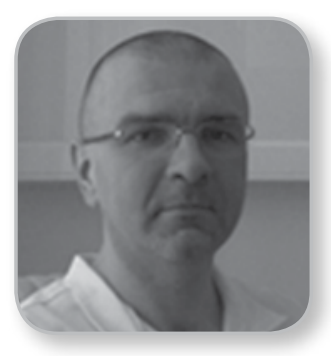

С.М. Діденко ${ }^{1}$, М.В. Свиридов ${ }^{2}$

${ }^{1}$ Клінічна лікарня «ФЕОФАНІЯ» Державного управління справами, м. Київ

${ }^{2}$ Украӥнський науково-практичний изентр ендокринної хірургї, трансплантації ендокринних органів і тканин МОЗ України, м. Київ

\section{ВСТУП}

За даними ВООЗ гангрена у хворих на цукровий діабет (ЦД) зустрічається в 30 разів частіше, ніж у хворих, які на діабет не хворіють. Високу ампутацію нижньої кінцівки пацієнтам із ЦД виконують в 10-12 разів частіше ніж пацієнтам без ЦД $[1,2]$.

Стенотично-оклюзійні ураження периферійних артерій у хворих на ЦД розвиваються на 10-15 років раніше, ніж у хворих на облітеруючий атеросклероз без діабету, прогресують швидше, мають більш злоякісний перебіг та частіше призводять до тяжких виразково-некротичних уражень стопи. Для ураження периферійного артеріального русла притаманний багаторівневий стенотичнооклюзійний процес в артеріях стегнового сегменту В поєднанні 3 ураженням артерій підколінногомілкового сегменту [3].

Специфічними морфологічними проявами ураження артерій гомілкового сегменту у хворих на ЦД $\epsilon$ медіакальциноз Менкеберга та дифузний фіброз інтими, що суттєво обмежує можливості застосування традиційних артеріальних реконструкцій [4].

Наявність хронічної критичної ішемії нижніх кінцівок (ХКІНК) свідчить про поганий прогноз. Згідно трансатлантичного консенсусу, протягом року після маніфестації ХKІНК лише 25\% хворих одужують, у 20\% симптоматика зберігається, у 30\% пацієнтів ампутують кінцівку, а 25\% - помирають [5].

2011 року Міжнародна робоча група з діабетичної стопи(IWGDF) прийняла рекомендації з діагностики та лікування захворювань периферійних артерій у хворих на ЦД із виразками стопи. Згідно 3 даними рекомендаціями, «мета реваскуляризації у цих пацієнтів полягає у відновленні прямого пульсуючого кровотоку як мінімум по одній артерії стопи, переважно по артерії, яка живить анатомічну зону виразки». Дане твердження стало результатом цілої низки досліджень, які довели перевагу ангіосомного принципу реваскуляризації [6].

Особливо складних тактичних та технічних рішень потребує група хворих на ішемічну форму синдрому діабетичної стопи (ІФ СДС) з поєднанням оклюзії поверхневої стегнової артерії (ПСА) та стенотичнооклюзійного ураження артерій підколінногомілкового сегменту, в яких застосування стандартних методів артеріальних реконструкцій зазвичай малоефективне. Актуальним залишається необхідність розробки та впровадження нових ефективних методів хірургічного лікування багаторівневого стенотично-оклюзійного ураження периферійних артерій у хворих на ЦД, таких, як гібридні артеріальні реконструкції [7].

Мета - визначити показання до виконання гібридних артеріальних реконструкцій у хворих з ІФ СДС та ХКІНК і проаналізувати їх ефективність.

\section{МАТЕРІАЛИ ТА МЕТОДИ}

Проведений аналіз результатів хірургічного лікування 126 хворих на ІФ СДС, зумовлений оклюзієюПСАв поєднанні зі стенотично-оклюзійним ураженням артерій підколінно-гомілкового сегменту на тлі ХКІНК, якізнаходились на лікуванні в Центрі судинної хірургії КЛ «ФЕОФАНІЯ» ДУС протягом 2014-2017 років. Частина хворих (12\%) проходила подальшу реабілітацію $з$ виконанням 
оперативних втручань на стопі у відділенні діабетичної стопи УНПЦ ендокринної хірургії, трансплантації ендокринних органів і тканин МО3 України. Чоловіків було 72, жінок - 54. Середній вік становив $67 \pm 4,6$ року, тривалість захворювання на

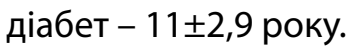

Всім пацієнтам проводили вимірювання сегментарного тиску з визначенням кісточковоплечового індексу за допомогою портативного ультразвукового апарату «Super Dopplex» (Китай); ультразвукове дуплексне сканування артерій нижніх кінцівок з вивченням характеру кровотоку на апараті «Flexfocus» виробництва «BK medical»(Данія), визначали черезшкірний парціальний тиск кисню $\left(\mathrm{T}_{\mathrm{cp}} \mathrm{O}_{2}\right)$ в тканинах стопи за допомогою апарату «TCM 400» виробництва «Radiometer» (Данія). Ангіографію виконували шляхом пункції загальної або поверхневої стегнової артерії під контролем ультразвуку за допомогою агіографічної системи «Euro Ampli Alien» виробництва «Eurocolumbus SRL» (Італія).

Усі 126 пацієнтів із багаторівневим ураженням артерійнижніх кінцівокбули розподіленінадвігрупи. Першу (дослідну) групу склали 65 пацієнтів (51,6\%), яким 3 метою корекції явищ ХКІНК була виконана гібридна артеріальна реконструкція: відновлення прохідності ПСА шляхом шунтування (тип ураження C або D за TASCII) або ендартеректомії (тип ураження A або В за TASCII) в поєднанні з балонною ангіопластикою (БАП) підколінної артерії (ПКА), тібіоперонеального стовбуру (ТПС) та гомілкових артерій (ГА) в різних комбінаціях. До другої (група порівняння) увійшов 61 пацієнт (48,4\%), якимбуло виконано відновлення прохідності ПСА шляхом шунтування або ендартеректомії без втручання на артеріях підколінно-гомілкового сегменту.

Послідовність виконання етапів гібридних артеріальних реконструкцій у пацієнтів першої групи $(\mathrm{n}=65)$ наведена на рис. 1.
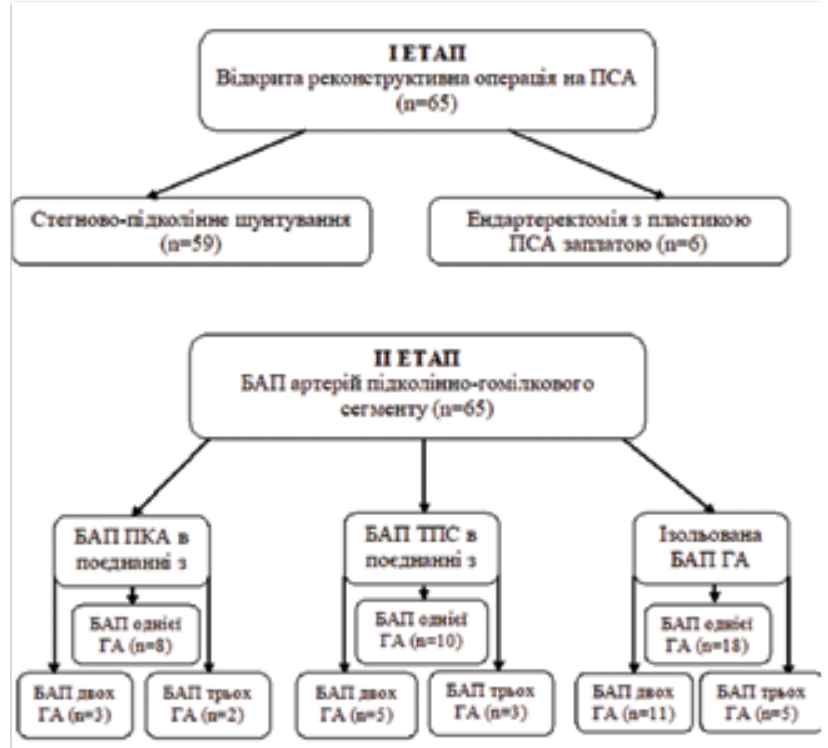

Puc. 1. Послідовність виконання етапів гібридних артеріальних реконструкцій у пацієнтів першої групи. Примітки: БАП - балонна ангіопластика; ПКА - підколінна артерія;ПСА - поверхнева стегнова артерія; ТПС - тібіоперонеальний стовбур; ГА - гомілкові артерії.

3 метою реконструкції ПСА у 59 (90,8\%) пацієнтів першої групи виконали стегново-підколінне шунтування. Ендартеректомію 3 пластикою заплатою виконали у $6(9,2 \%)$ пацієнтів. Показанням для виконання стегново-підколінного шунтування вважали протяжну оклюзію ПСА (більше 5 см) та наявність виразної кальцифікації стінки. Показанням для виконання ендартеректомії вважали короткий (до 5 см) сегмент ПСА, що підлягав реконструкції, та відсутність кальцифікації стінки артерії.

Зазвичай БАП артерій підколінно-гомілкового сегменту в $36(55,4 \%)$ спостережень була виконана у вигляді пластики однієї ГА ізольовано, або в поєднанні з пластикою ПКА чи ТПС, тому що згідно рекомендацій IWGDF (2011) «мета реваскуляризації у цих пацієнтів полягає у відновленні прямого

Типи шунтів для реконструкції ПСА

\begin{tabular}{|c|c|c|c|}
\hline Група хворих & Синтетичний протез & Комбінований шунт & Загалом \\
\hline Перша & 47 & 12 & 59 \\
\hline Друга & 35 & 22 & 57 \\
\hline
\end{tabular}


Локалізація дистальних анастомозів стегново-підколінних шунтів

\begin{tabular}{|c|c|c|c|c|}
\hline Група хворих & ПСА & ПКА вище коліна & ПКА нижче коліна & Загалом \\
\hline Перша & 28 & 21 & 10 & 59 \\
\hline Друга & 19 & 15 & 23 & 57 \\
\hline
\end{tabular}

пульсуючого кровотоку як мінімум по одній артерії стопи, переважно по артерії, яка живить анатомічну зону виразки». Ми завжди намагалися виконати БАП двох або трьох ГА, що збільшує ємність дистального русла та покращує прогноз первинної прохідності зони артеріальної реконструкції, але на прогноз загоєння ішемічних виразково-некротичних уражень не впливає.

У 57 пацієнтів другої групи була виконана реконструкція ПСА шляхом шунтуванняіу 4-шляхом ендартеректомії з пластикою артерії заплатою.

Шунтування в першій та другій групах були виконані 3 застосуванням синтетичних протезів або комбінованих шунтів (синтетичний протез + сегмент аутовени). Типи шунтів для реконструкції ПСА наведені в таблиці 1.

Широке використання синтетичних протезів у якості шунтів ми пояснюємо необхідністю збереження великої підшкірної вени для можливого в перспективі аорто-коронарного або повторного периферійного шунтування, «розсипним» типом анатомії підшкірних вен нижньої кінцівки або венектомією в анамнезі.

При необхідності формування дистального анастомозу 3 підколінною артерією нижче щілини колінного суглобу завжди намагалися робити шунтування комбінованим шунтом. Варіантилокалізації дистальних анастомозів стегново-підколінних шунтів наведені в таблиці 2.

Ендартеректомію виконували при короткій (до 5 см) оклюзії поверхневої стегнової артерії відкритим способом або за допомогою кілець Vollmar. В якості заплати для пластики ПСА після ендартеректомії використовували сегмент однієї з приток великої підшкірної вени 3 метою зберегти останню неушкодженою.

БАП артерій підколінно-гомілкового сегменту проводили наступним чином:голкою для ангіографії виконували пункцію вже функціонуючого стегново- підколінного шунта та вводили по провіднику інтродюсер4-6F.ДляБАПзастосовували периферійні балони діаметром 2-5 мм на провідниках 0,014' 0,035'. Балони роздували протягом 1-2 хвилин до тиску 8-12 Атм, за потреби повторювали процедуру 2-3 рази. Після проведення ангіопластики інтродюсер видаляли 3 шунта, а отвір в шунті зашивали атравматичною ниткою 5-0 Prolene.

Ефективність реваскуляризаційної операції оцінювали за допомогою транскутанної оксиметрії через 10 діб після відновлення кровообігу в нижньої кінцівці, якщо ці показники збільшувалися більш ніж 30 мм рт. ст. Для профілактики тромбоутворення всім хворим призначали Клопідогрель 75 мг 1 раз на добу пожиттєво згідно міжнародних стандартів та протоколів лікування цієї патології. Безпосередньо в ранньому післяопераційному періоді глікемію корегували дрібними дозами простого інсуліну короткої дії, а після виписки пацієнти переходили на звичайну схему лікування ЦД згідно показників цукру крові під контролем ендокринолога.

\section{РЕЗУЛЬТАТИ}

Протягом періоду післяопераційного спостереження, який в середньому становив 12 місяців, з 65 пацієнтів першої групи у 6 виник тромбоз зони стегново-підколінної реконструкції. Усім 6 пацієнтам були виконані тромбектомія 3 шунта 3 інтраопераційною ангіографією, під час якої був знайдений рестеноз артерій підколінногомілкового сегменту, та виконана повторна ангіопластика. У 4 хворих втручання виконані 3 хорошим результатом. У 2 хворих регресу ішемії досягти не вдалося, їм виконана ампутація на рівні гомілки. У 1 хворого виконана ампутація на рівні стегна в зв'язку з нагноєнням шунта.

361 пацієнта контрольної групи, яким було виконано ізольовану артеріальну реконструкцію стегнового сегменту, протягом періоду 
спостереження у 21 пацієнта виник тромбоз зони стегново-підколінної реконструкції. Пацієнтам були виконані тромбектомія з шунта та ангіографія, на якій було констатовано багаторівневе стенотичнооклюзійне ураження артерій підколінногомілкового сегменту. В 10 хворих була виконана ангіопластика - у 7 з позитивним результатом, у 3 хворих виконана висока ампутація. 311 хворих, яким ангіопластика не виконувалась, у 8 хворих виконана висока ампутація.

Таким чином, первинна прохідність зони стегнової реконструкції у пацієнтів першої групи за умови застосування методів гібридної хірургії протягом періоду спостереження становила 90,8\%,частота збереження кінцівки - 95,4\%. У пацієнтів другої групи, яким була виконана ізольована реконструкція стегнового артеріального сегменту, первинна прохідність зони стегнової реконструкції становила 65,6\%, частота збереження кінцівки - 82\%. Результати хірургічного лікування хворих першої та другої групи наведені в таблиці 3.

\section{ОБГОВОРЕННЯ}

Поєднання оклюзії ПСА зі стенотично-оклюзійним ураженням артерій підколінно-гомілкового сегменту у хворих на ІФ СДС потребує складних тактичних та технічних рішень,застосування сучасних методів обстеження та новітніх технологій лікування. Стандартні методики відновлення прохідності оклюзованого стегнового артеріального сегмента за наявності стенотично-оклюзійного ураження артерій підколінно-гомілкового сегменту, такі, як ізольоване стегново-підколінне шунтування або ендартеректомія, без втручання на артеріях гомілки часто не дають позитивного результату. У 34,4\% хворих 3 такою патологією протягом 12 місяців виникає необхідність виконання повторних операцій на артеріях, а у 18\% - високих ампутацій нижньої кінцівки. 3 одного боку, стенотично-оклюзійне ураження артерій підколінно-гомілкового сегменту $\epsilon$ провокуючим фактором тромбозу зони реконструкції стегнового сегменту, з іншого - перешкоджає відновленню кровопостачання стопи через реконструйований стегновий сегмент та погіршуєперспективу загоєння ішемічних виразково-некротичних уражень. Все це переконливо свідчить про необхідність поєднання відкритих та ендоваскулярних хірургічних методик в лікуванні даної складної категорії хворих. Отже, оптимальним сучасним методом хірургічного лікування хворих 3 поєднаним стенотичнооклюзійним ураженням стегнового та підколінногомілкового артеріальних сегментів $\epsilon$ гібридна реконструктивна операція.

\section{ВИСНОВКИ}

1. У хворих 3 ішемічною формою синдрому діабетичної стопи, зумовленого оклюзією поверхневої стегнової артерії в поєднанні зі стенотично-оклюзійним ураженням артерій підколінно-гомілкового сегменту на тлі хронічної критичної ішемії нижніх кінцівок, оптимальним сучасним методом хірургічного лікування $\epsilon$ виконання гібридної артеріальної реконструкції відновлення прохідності ПСА шляхом шунтування або ендартеректомії в поєднанні 3 балонною ангіопластикою підколінно-гомілкового артеріального сегменту.

2. Виконання гібридних артеріальних реконструкцій дозволило протягом періоду спостереження зменшити частоту тромбозів зони артеріальної реконструкції після первинної операції в 3,7 рази, а частоту виконання високих ампутації в 3,9 рази порівняно з хворими, яким виконували лише відновлення прохідності поверхневої стегнової артерії.

\section{ЛІТЕРАТУРА}

Таблиця 3

Результати хірургічного лікування хворих першої та другої групи

\begin{tabular}{|c|c|c|c|}
\hline Група хворих & $\begin{array}{c}\text { Первинна прохідність } \\
\text { зони реконструкції ПСА }\end{array}$ & Збереження кінцівки & Висока ампутація \\
\hline Перша $(\mathrm{n}=65)$ & $59(90,8 \%)$ & $62(95,4 \%)$ & $3(4,6 \%)$ \\
\hline Друга $(\mathrm{n}=61)$ & $40(65,6 \%)$ & $50(82 \%)$ & $11(18 \%)$ \\
\hline
\end{tabular}


1. Особенности хирургической тактики при многоуровневых окклюзионно-стенотических поражениях бедренно-берцового артериальных сегментов / П.И. Никульников, А.А. Быцай, А.В. Ратушнюк, А.В. Лискунов. // Харківська хірургічна школа. - 2013. - №3. - С. 148-151.

2. Питык А. И. Альтернативные подходы к эндоваскулярной реваскуляризации нижних конечностей у больных с критической ишемией / А. И. Питык. // Серце і судини. - 2015. - №1 (49). - С. 70-76.

3. Thiruvoipati T. Peripheral artery disease in patients with diabetes: Epidemiology, mechanisms, and outcomes / T. Thiruvoipati, C. E. Kielhorn, E. J. Armstrong. // World Journal of Diabetes. - 2015. Vol. 6. - P. 961-969.

4. Arteriographic findings in diabetic and nondiabetic patients with critical limb ischemia / [V. Santos, C. Alves, C. Fidelis та ін.]. // Rev. Assoc. Med. Bras. 2013. - Vol. 59, N. 6. - P. 557-562.

5. Inter-Society Consensus for the management of peripheral arterial disease (TASC II) / [L. Norgren, W. R. Hiatt, J. A. Dormandy та ін.]. // J Vasc Surg. - 2007. - Vol. 45, Suppl. S. - P. 5-67.

6. Diagnosis and treatment of peripheral arterial disease in diabetic patients with a foot ulcer. A progress report of the International Working Group on the Diabetic Foot / [N. C. Schaper, G. Andros, J. Apelqvist та ін.]. // Metab Res Rev. - 2012. - Vol. 28, Suppl. 1. - P. 218-224.

7. Endovascular first as "preliminary approach" for critical limb ischemia and diabetic foot. / [C. Setacci, P. Sirignano, G. Galzerano та ін.]. // J Cardiovasc Surg (Torino). - 2013. - Vol. 54, N. 6. - P. 679-684.

\section{REFERENCES}

1. Nikulnikov PI, Bytsay AA, Ratushnyuk AV, Liskunov $A V$. [Pecularities of surgical treatment in multilevel occlusive-stenotic lesions of femoral-tibial arterial segments]. Kharkivska Khirurhichna Shkola. 2013; (3):148-151. [Russian].

2. Pityk Al. [Alternative approaches to endovascular revascularization of lower limbs in patients with critical ischemia]. Sertse i Sudyny. 2015; (1):70-76. [Russian].

3. Thiruvoipati T, Kielhorn CE, Armstrong EJ. Peripheral artery disease in patients with diabetes: Epidemiology, mechanisms, and outcomes. World J Diabetes. 2015 Jul 10; 6(7):961-9.

4. Santos VP, Alves CA, Fidelis C, Araújo Filho JS.
Arteriographic findings in diabetic and non-diabetic with critical limb ischemia. Rev Assoc Med Bras (1992). 2013 Nov-Dec; 59(6):557-62.

5. Norgren L, Hiatt WR, Dormandy JA, Nehler MR, Harris $K A$, Fowkes FG; TASC II Working Group. Inter-Society Consensus for the Management of Peripheral Arterial Disease (TASC II). J Vasc Surg. 2007 Jan; 45Suppl S:S5-67.

6. Schaper NC, Andros G, Apelqvist J, Bakker K, et al. Diagnosis and treatment of peripheral arterial disease in diabetic patients with a foot ulcer. A progress report of the International Working Group on the Diabetic Foot. Diabetes Metab Res Rev. 2012 Feb; 28 Suppl 1:218-24.

7. SetacciC, Sirignano $P$, Galzerano G, et al. Endovascular first as "preliminary approach" for critical limb ischemia and diabetic foot. J Cardiovasc Surg (Torino). 2013 Dec; 54(6):679-84.

\section{PEЗЮME}

\section{Ефективність гібридних артеріальних реконструкцій у хворих на цукровий діабет із критичною ішемією нижньої кінцівки С.М. Діденко, М.В.Свиридов}

Вступ. Актуальним напрямком судинної хірургії $\epsilon$ впровадження нових ефективних методів хірургічного лікування багаторівневого стенотичнооклюзійного ураження периферійних артерій у хворих на цукровий діабет (ЦД), таких, як гібридні артеріальні реконструкції.

Мета - визначити показання до виконання гібридних артеріальних реконструкцій у хворих 3 ішемічною формою синдрому діабетичної стопи (ІФ СДС) та хронічною критичною ішемією нижніх кінцівок (ХКІНК), проаналізуватиїх ефективність.

Матеріали та методи. Проаналізовано результати хірургічного лікування 126 хворих на ІФ СДС, зумовленого оклюзією поверхневої стегнової артерії (ПСА) в поєднанні зі стенотично-оклюзійним ураженнямартерійпідколінно-гомілковогосегменту на тлі XКІНК. До першої групи увійшли 65 пацієнтів $(51,6 \%)$, яким була виконана гібридна артеріальна реконструкція: відновлення прохідності стегнового артеріального сегменту в поєднанні з балонною ангіопластикою артерій підколінно-гомілкового сегменту. До другої групи увійшов61 пацієнт (48,4\%), яким було виконано відновлення прохідності стегнового артеріального сегменту без втручання на артеріях підколінно-гомілкового сегменту.

Результати. У хворих першої групи за 
умови застосування методів гібридної хірургії первиннапрохідність зони артеріальної реконструкціїпротягом періоду спостереження становила 90,8\%, частота збереження кінцівки 95,4\%. У другій групі після виконання ізольованої реконструкції в стегновому артеріальному сегменті без втручання на артеріях підколінно-гомілкового сегменту протягом 12 місяців у 34,4\% хворих розвинувся тромбоз із необхідністю виконання повторних операцій на артеріях, а у 18\% хворих виникла необхідність виконання високих ампутацій нижньої кінцівки. Відповідно, первинна прохідність зони стегнової реконструкції в другій групі становила 65,6\%, частота збереження кінцівки $82 \%$.

Висновки. У пацієнтів з ІФ СДС, зумовленого оклюзієюПСА в поєднанні зі стенотично-оклюзійним ураженнямартерійпідколінно-гомілковогосегменту на тлі ХКІНК,оптимальним методом хірургічного лікування $\epsilon$ гібридна реконструктивна операція. Застосування гібридної методики дозволило протягом періоду спостереження зменшити частоту тромбозів зони артеріальної реконструкції після первинної операції в 3,7 рази, а частоту виконання високих ампутацій - в 3,9 рази порівняно з хворими, яким виконували лише відновлення прохідності ПСА.

Ключові слова: цукровий діабет,хронічна критична ішемія нижньої кінцівки, синдром діабетичної стопи, гібридна артеріальна реконструкція, шунтування, балонна ангіопластика.

\section{PEЗЮME}

\section{Эффективность гибридных реконструкций у} больных сахарным диабетом с критической ишемией нижней конечности

\section{С.М. Диденко, Н.В. Свиридов}

Введение. Актуальным направлением сосудистой хирургии является внедрение новых эффективных методов хирургического лечения многоуровневого окклюзионно-стенотического

поражения периферических артерий у больных сахарным диабетом (СД), таких как гибридные артериальные реконструкции.

Цель - определить показания к
выполнениюгибридных
реконструкций у пациентов с ишемической формой синдрома диабетической стопы (ИФ СДС) и хронической критической ишемией нижних конечностей (ХКИНК), проанализировать их эффективность.

Материалы и методы. Проанализированы результаты хирургического лечения 126 пациентов С ИФСДС, обусловленного окклюзией поверхностной бедренной артерии (ПБА) в сочетании с окклюзионно-стенотическим поражением артерий подколенно-берцового сегмента на фоне ХКИНК. В первую группу вошло 65 пациентов (51,6\%), которым была выполнена гибридная артериальная реконструкция: восстановление проходимости бедренного артериального сегмента в сочетании с баллонной ангиопластикой артерий подколенноберцового сегмента. Во вторую группу вошел 61 пациент (48,4\%), которым было выполнено восстановление проходимости бедренного артериального сегмента без вмешательства на артериях подколенно-берцового сегмента.

Результаты. У больных первой группы при условии применения методов гибридной хирургии первичная проходимость зоны артериальной реконструкции в течение периода наблюдения составила 90,8\%, частота сохранения конечности $-95,4 \%$. Во второй группе после выполнения изолированной реконструкции В бедренном артериальном сегменте без вмешательства на артериях подколенно-берцового сегмента в течение 12 мес у 34,4\% больных развился тромбоз с необходимостью выполнения повторных операций на артериях, а у $18 \%$ больных возникла необходимость выполнения высоких ампутаций нижней конечности. Соответственно, первичная проходимость зоны бедренной реконструкции во второй группе составила 65,6\%, частота сохранения конечности $-82 \%$.

Выводы. У пациентов с ИФ СДС, обусловленного окклюзией ПБА в сочетании со окклюзионностенотическим поражением артерий подколенноберцового сегмента на фоне ХКИНК, оптимальным методом хирургического лечения является гибридная реконструктивная операция. Применение гибридной методики позволило в течение периода наблюдения уменьшить частоту тромбозов зоны артериальной реконструкции после первичной операции в 3,7 раза, а частоту выполнения высоких ампутаций - в 3,9 раза в сравнении с больными, у которых выполняли только восстановление проходимости ПБА.

Ключевые слова: сахарный диабет, хроническая критическая ишемия нижней конечности, синдром диабетической стопы, гибридная артериальная 
реконструкция, ангиопластика.

шунтирование,

баллонная

\section{SUMMARY}

Efficiency of hybrid arterial reconstructions in patients with diabetes with critical ischemia of the lower limb

\section{Didenko SM, Svyrydov MV}

Introduction. The need to introduce new efficient methods of surgical treatment of multi-level stenoticocclusive lesions of peripheral arteries in patiens with diabetes, such as hybrid arterial reconstruction, remains actual.

Aim - to determine the indications for hybrid arterial reconstruction in patients with ischemic form of diabetic foot syndrome (IF DFS) and chronic critical ischemia of the lower limb (CCILL) and analyze their effectiveness.

Materials and methods. The analysis of the results of surgical treatment in 126 patients with IF DFS due to occlusion of superficial femoral artery(SFA) in conjunction with the stenotic-occlusive affection of the arteries of the popliteo-tibial segments on the background of CCILL was carried out. The first group included 65 patients (51.6\%) who underwent a hybrid arterial reconstruction: restoration of the patency of the femoral arterial segment in combination with balloon angioplasty of arteries of the popliteo-tibial segment. The second one included 61 patients (48.4\%) who underwent restoration of the patency of the femoral arterial segment without intervention in the popliteotibial segment.

Results. In the first group primary patency of the arterial reconstruction zone with the use of methods of hybrid surgery during the observation period was $90.8 \%$, limb preservation $-95.4 \%$. In the second group after the isolated reconstruction in the femoral arterial segment without intervention in the popliteo-tibial segment thrombosis developed in $34.4 \%$ of patients within 12 months with need of reoperation, in $18 \%$ patients the need of high amputations of lower limb occurred.

Correspondingly, in the second group, the primary patency of the femoral reconstruction zone was $65.6 \%$, while the limb was preserved in $82 \%$.

Conclusion. In patients with IF DFS due to occlusion of SFA in conjunction with the stenoticocclusive affection of the arteries of the popliteotibial segment on the background of CCILL the hybrid arterial reconstruction is the optimal method of surgical treatment. Implementation of hybrid arterial reconstruction allowed to reduce the frequency of thrombosis in the arterial reconstruction zone after the primary operation 3.7 times, and the frequency of high amputation 3.9 times during the observation period, compared with patients underwent the patency restoration in SFA only.

Key words: diabetes mellitus, chronic critical ischemia of the lower limb, diabetic foot syndrome, hybrid arterial reconstruction, bypass surgery, balloon angioplasty. 